\title{
"Can we take a picture with you?" The realization of the refusal speech act with tourists by Emirati speakers
}

\author{
Tanju DEVECI and Jessica MIDRAJ \\ Khalifa University of Science and Technology \\ Abu Dhabi, UAE
}

\begin{abstract}
Effective communication between people from different cultures requires not only the ability to speak a common language but also an awareness of sociocultural rules and sociolinguistics features, an important one being speech acts the realization of which realization by Emirati non-native speakers of English has not been studied sufficiently. This paper investigates a particularly facethreatening speech act - refusals. It explores Emiratis' comfort level and the use of the refusal speech act in communicative exchanges with unknown tourists. The data set consisted of 94 participant responses to a pre-instructional activity in an introductory linguistics class. Both descriptive and inferential statistics were used to analyze the data sets. The key findings suggest that both male and female participants were rather comfortable conversing with a tourist couple that they had never met, but male participants reported being more at ease accepting the couple's request to take a photo with the tourists at a statistically significant level. While more than half of the participants reported willingness to take the photo with the tourists, approximately $41.5 \%$ would decline such a request, with significantly more females declining the request. The most frequent components of the refusal speech act included a statement of regret, a thank-you note, and an excuse, reason, or explanation. Results also showed that linguistic devices for positive politeness purposes were used rather sparingly, and it was mainly the females who used them. Based on the results, it is helpful for visitors to the UAE to be mindful of Emiratis' sociocultural and sociolinguistic behaviors so that the nuances of communication can be understood and responses are appropriate, which can reduce the likelihood of communication breakdowns and increase the well-being of all involved in the interaction.
\end{abstract}

Keywords: Refusal, speech act, Emirati speakers, tourists, socio-cultural rules

\section{For citation:}

Deveci, Tanju \& Jessica Midraj. 2021. “Can we take a picture with you?” The realization of the refusal speech act with tourists by Emirati Speakers. Russian Journal of Linguistics 25 (1). 68-88. DOI: 10.22363/2687-0088-2021-25-1-68-88 


\title{
«Можно с вами сфотографироваться?» \\ Реализация речевого акта отказа
}

в коммуникации жителей Арабских Эмиратов с туристами

\author{
Танджу ДЕВЕЧИ, Джессика МИДРАДЖ
}

Научно-технологический университет Халифа

Абу-Даби, ОАЭ

\begin{abstract}
Аннотация
Эффективная коммуникация между жителями разных стран требует не только способности говорить на общем языке, но и знания социокультурных правил и социолингвистических особенностей, включая речевые акты. В статье рассматривается речевой акт отказа, представляющий особую угрозу для лица собеседника. Его реализация неносителями английского языка из Арабских Эмиратов еще недостаточно изучена. Исследуется уровень комфорта жителей Эмиратов при выражении отказа в общении с незнакомыми туристами. Материалом исследования послужили 94 реакции респондентов на приглашение туристов совместно сфотографироваться. Предварительно на вводном лингвистическом занятии участникам были даны инструкции. Для анализа полученных данных использовалась описательная и инференциальная статистика. Результаты показывают, что как мужчинам, так и женщинам, было достаточно комфортно разговаривать с туристами, однако мужчины - участники исследования - чувствовали себя более непринужденно, соглашаясь сфотографироваться с ними. Хотя более половины участников сообщили о своей готовности сфотографироваться, приблизительно $41.5 \%$ отметили, что отказались бы выполнить такую просьбу, причем отказом ответило бы значительно больше женщин. Наиболее частотными компонентами речевого акта отказа были выражения сожаления, благодарности, извинения или объяснение причины отказа. Результаты также показали, что лингвистические приемы позитивной вежливости использовались достаточно редко, в основном женщинами. На основе полученных результатов можно сделать вывод, что приезжающим в ОАЭ следует принимать во внимание социокультурные и социолингвистические нюансы поведения местных жителей и реагировать на них соответствующим образом; это снизит вероятность коммуникативных сбоев и повысит уровень благополучия участников общения.
\end{abstract}

Ключевые слова: отказ, речевой акт, жители Эмиратов, туристы, социокультурные правила

\section{Для цитирования:}

Deveci T., Midraj J. "Can we take a picture with you?" The realization of the refusal speech act with tourists by Emirati Speakers. Russian Journal of Linguistics. 2021. Vol. 25. № 1. P. 68-88. DOI: 10.22363/2687-0088-2021-25-1-68-88

\section{Introduction}

Awareness of socio-cultural rules is a sine qua non for effective communication with people from other cultures. Not only does this awareness include social norms, but it also includes ways in which language should be used to achieve communication aims. Communication with people from the same sociocultural background is usually easier than that with those from foreign cultures. Given the advances in technology and increased opportunities for international travel, however, we interact with people from foreign cultures more frequently than 
ever. English appears to be the language in which people generally converse during such interactions. However, differences between cultural norms as well as between meanings of words may still cause challenges. This is particularly the case when communicators resort to direct translations from their first language (L1) into the foreign language (L2). Challenges can become even more formidable in situations where people are unaware of cultural variations. Therefore, our language competence largely depends on our "knowledge and ability in ways that are both grammatical and socially appropriate" (Bauman \& Sherzer 1975: 108). This necessitates the awareness of a variety of sociolinguistic features of the L2 in which one wishes to communicate, such as speech acts. That is, not only does effective intercultural communication require understanding of the sentence in its semantic meaning, but it also necessitates "pragmatic competence to understand and perform different speech acts in intercultural contexts" (Iliadi \& Larina 2017: 532).

Speech acts are "communicative activit[ies] ... defined with reference to the intentions of speakers while speaking ... and the effects they achieve on listeners" (Crystal 1985: 446). Much attention has been paid to the ways various speech acts are performed across cultures. These were often prompted by the need to assist people involved in the communication to use the language in socio-linguistically appropriate ways. This is particularly important in countries where the English language is predominantly used by people from different linguistic backgrounds for daily activities. One such country is the United Arab Emirates (UAE) with a staggering $88.52 \%$ of its residents being expatriates from various countries (GMI 2019). UAE has also been noted to attract an increasing number of tourists. For instance, 16.7 million tourists visited Dubai in 2019, which represented an increase of 5.1\% from the previous year (Dubai Tourism 2020). There has also been an increase in tourists visiting Abu Dhabi where there has been a move towards integrating tourism with the local cultures and values (Low 2012). The country's already-enhanced investment in the tourism and hospitality industry is expected to increase even further beyond 2020 with the development of theme parks, natural attractions and more affordable hotels (Tesorero 2019). Such an increase adds to the existing diversity of the cultures within the region, thus increasing the opportunity for peoples of different cultures to interact. However, this also brings language and culture-related challenges for the tourists, expatriates and Emiratis, requiring all parties to have intercultural communication competence (ICC) skills alongside language skills. ICC is "the ability to communicate effectively and appropriately with people of other cultures" (Spitzberg 2000 cited in Jandt 2018: 90). One of ICC's skill areas is cultural awareness, which involves understanding how the members of the host country think and behave during communication (Jandt 2018). People in some high-context cultures such as Russia may not make an effort to be polite to strangers and even refrain from having eye contact with them (Sokolskaya 2015). Previous research has also shown that Russians, in comparison to the British, "can be less formal and not vigilant in guarding their personal space" and "direct communication is socially acceptable 
and in some situations even preferred" (Larina 2015: 205). The lack of awareness of such cultural tendencies can create communication breakdowns.

Emiratis' use of the English language for various purposes has been investigated by researchers in such areas as writing (Deveci 2018, Nunn, Deveci \& Salih 2015, Al Murshidi 2014), speaking (Al Nawrasy 2013, Khameis 2007), and listening (Barlow 2009). However, their realization of speech acts has received little interest from researchers. In recent years, investigations have been conducted into Emiratis' realization of speech acts such as complaint (Deveci 2015), request (Deveci \& Hmida 2017), and compliment (Deveci, Midraj \& El Sokkary 2021) in communicating with expatriates. The results of these studies generally pointed to the participants' ways of performing speech acts. These results, coupled with the general dearth of studies into Emiratis' pragmatic tendencies during interactions with those from different cultures, prompted us to investigate their utilization of the refusal speech act. Given its highly face-threatening nature, the refusal speech act likely causes distress to the speaker. Likewise, the lack of awareness of Emiratis' communication tendencies and preferred ways of language use may result in the non-Emiratis feeling uneasy and awkward. Such situations' potential outcome is a lack of communication or miscommunication with undesirable impacts on both parties' overall well-being. As Larina, Ozyumenko and Kurtes (2017: 109) put it, "as daily interaction - professional, public, mediated, or otherwise - in an ever more globalized world requires finely developed intercultural skills, pragmatic competence and cultural fluency, having a deeper insight into the intricate relationship between language, communication and (ethnic) identity is of critical importance."

To elucidate Emirati propensities for interactions with foreign tourists and help reduce the aforementioned potential problems, the current study, therefore, aimed to answer the following questions:

1- How comfortable do Emiratis feel talking to a tourist couple that they have never met before?

2- What is the extent to which they would feel comfortable accepting a tourist couple's request for a photo with the couple in their traditional Emirati clothes?

3- What are the components of the refusal speech act set produced by the participants in response to a tourist couple requesting a photo with them in their traditional Emirati clothes?

\section{Theoretical Background}

In this paper, refusals are examined through the perspective of speech act theory, the foundations of which lie in Austin's (1962) seminal work How to Do Things with Words. In this book, Austin proposed the term "performative utterances ${ }^{1}$," which is derived from the verb "perform." According to Austin, in uttering a sentence, we do not describe what is being done. Rather, we do it. This

\footnotetext{
${ }^{1}$ An utterance is a functional unit in communication (Richards, Platt \& Weber 1985).
} 
formed the basis of the speech act theory put forward by Searle (1977). Searle (2002) identified five types of illocutionary acts: assertives, directives, commissives, expressives, and declarations. Moreno (2002 cited in Félix-Brasdefer 2009: 3) notes that "[r]efusals are second pair parts in conversation and belong to the speech act of dissent which represents one type of assertive act or negative expression." Refusals are normally produced in response to a request, an invitation, a suggestion or an offer (Merhpour, Ahmadi \& SabourianZadeh 2016). Since they commit the refuter to perform an action, refusals can also function as a type of commissive (Searle 1977).

Refusals can be direct or indirect (Beebe, Takahashi \& Uliss-Weltz 1990). Direct refusals are straightforward regarding the intended meaning and can be both performative and non-performative. The former includes a self-naming utterance (e.g., "I refuse"), "in which the performative verb usually refers to the act in which the speaker is involved at the moment of speech" (Leech 1983: 215), whereas the latter includes the negation word 'No' or expressions of a lack of willingness or ability such as "I won't," "I don't think so," and "I cannot." Indirect refusals, on the other hand, are performed to reduce the impact of the face-threatening act (e.g., "Unfortunately, I have another meeting at that time"). The refusal speech act set may include any of the following components in Table 1 below.

Table 1

Components of the Refusal Speech Act Set*

\begin{tabular}{|l|l|}
\hline \multicolumn{1}{|c|}{ Components } & \multicolumn{1}{c|}{ Examples } \\
\hline Statement of regret & I'm sorry but I can't do it. \\
\hline Wish & I wish I could help you. \\
\hline Excuse, reason, explanation & My children will be home that night. \\
\hline Statement of alternative & Why don't you ask someone else? \\
\hline $\begin{array}{l}\text { Set condition for future or past } \\
\text { acceptance }\end{array}$ & If you'd asked me earlier, I would have ... \\
\hline Promise of future acceptance & I'll do it next time. \\
\hline Statement of principle & I don't take pictures with strangers. \\
\hline Attempt to dissuade the interlocutor & \\
\hline $\begin{array}{l}\text { a. } \text { Threat or statement of negative } \\
\text { consequences to the requester }\end{array}$ & The picture will not be great because I look terrible. \\
\hline $\begin{array}{l}\text { b. Guilt trip } \\
\text { c. Criticize the request/requester }\end{array}$ & $\begin{array}{l}\text { I can't make a living off people who just order coffee. (a } \\
\text { waitress speaking to customers who want to sit a while) }\end{array}$ \\
\hline $\begin{array}{l}\text { d. Request for help, empathy, } \\
\text { and assistance by dropping or holding } \\
\text { the request }\end{array}$ & That's a terrible idea! \\
\hline e. Let interlocutor off the hook & It would be helpful if you could ask me in an hour. \\
\hline \multicolumn{1}{|c|}{ f. Self-defense } & Don't worry about it. \\
\hline Acceptance that functions as a refusal & I'm trying my best. \\
\hline \begin{tabular}{l} 
a. Unspecific or indefinite reply \\
\hline b. Lack of enthusiasm
\end{tabular} & Maybe. \\
\hline & I don't know if that is a good idea. \\
\hline
\end{tabular}


Deveci Tanju and Jessica Midraj. 2021. Russian Journal of Linguistics 25 (1). 68-88

\begin{tabular}{|l|l|}
\hline \multicolumn{1}{|c|}{ Components } & \multicolumn{1}{|c|}{ Examples } \\
\hline $\begin{array}{l}\text { Avoidance } \\
\text { a. Nonverbal } \\
\text { - Silence/Hesitation/Do nothing/ } \\
\text { Physical departure }\end{array}$ & \\
\hline $\begin{array}{l}\text { b. Verbal } \\
\text { - Topic switch } \\
\text { - Joke }\end{array}$ & What other places have you visited while in the UAE? \\
\hline - Repetition of part of the request & A photo with me? I am not a celebrity, am I? \\
\hline - Postponement & I'll think about it. \\
\hline - Hedging & I' m not sure. \\
\hline
\end{tabular}

* Adapted from Beebe et al. (1990: 73)

As is seen above, when performing a refusal in response to another speech act such as a request or a compliment, distinct speech acts can be produced (Chen cited in Tanck 2004). First, there may be an expression of remorse (e.g. "I'm sorry"). This may be followed by a direct refusal (e.g. "I can't do it"), and finally an excuse (e.g. "It is against my culture"). The order in which these appear is likely to change depending on the speech act in response to which refusals are performed. For instance, a refuter probably produces the speech act of thanking before refusing if he/she is responding to a compliment.

Beebe et al. (1990) also note that a refusal may be accompanied by a variety of adjuncts to alleviate the impact. Among these are:

1. Statement of positive opinion/feeling or agreement (e.g., "That's a good idea...")

2. Statement of empathy (e.g., "I realize you are in a difficult situation.")

3. Pause fillers (e.g., "uhh", "well")

4. Gratitude/appreciation

With possible negative impacts on both the hearer and the speaker, refusals can be a particularly face-threatening act (Brown \& Levinson 1987). In producing a refusal, the speaker fails to meet the expectation of the interlocutor, which may lead to the speaker coming across as disapproving or disrespectful. The hearer may take this act as a sign of impoliteness (Shishavan \& Sharifian 2016). As a result, refusals may affect both parties negatively, with likely impacts on their social standing (Brown \& Levinson 1987), psychological well-being (Leary 2015), and even physical health (Kross et al. 2011). These may be more to the detriment of the hearer than to the speaker (Johnson, Roloffm \& Riffee 2004). Even so, the speaker may choose not to refuse at the expense of his/her peace of mind. Therefore, a refusal may be considered a cultural act before it is a linguistic one (Iliadi \& Larina 2017, Mokhtari 2015).

The influence of gender on speech acts of refusal seems to be variable depending on a multitude of sociocultural factors. Nelson, Batal, and Bakary (2002) found that Egyptian males were more likely to use a direct refusal than Egyptian females when interacting with an interlocutor from either a higher or lower status 
in their first language. Similarly, in a study of 50 Persian, Kurdish, Turkish, and Arab speakers of English at the postgraduate level in Cyprus, it was found that while most utilized indirect refusals, male participants were more likely to employ direct rejections with interlocutors of lower status, while females tended to use them with those of equal status (Rezvani, Ismael \& Tok 2017). The same researchers also found that females utilized more adjuncts with lower, equal and higher status interlocutors. Tuncer and Turhan (2019) explored the refusal strategies used by 27 Turkish first-year pre-service teachers of English and discovered that males used "no" more often, while females employed "negative willingness" more regularly. Moreover, they noted that females tended to utilize more refusal techniques with lower and equal status interlocutors, while males used more with interlocutors at a higher status (2019). However, Abed (2011), who investigated university-level Iraqi speakers of English, found insignificant differences between males and females in their use of refusals and adjuncts. Likewise, a study about the use of refusal strategies with Iranian speakers of English found little difference between females and males in their use of refusals at all social status levels (Hedayatnejad, Maleki \& Mehrizi 2015). Therefore, research demonstrates that differences between the genders in the use of refusals is inconsistent and may depend on various other factors.

Refusals exist in all languages; however, the ways and the contexts in which they are performed [or not] differ across cultures (Chojimah 2015). Speakers, therefore, need to be mindful of ways in which they should perform and react to refusals as these are considered to be "a major cross-cultural "sticking point" for many nonnative speakers, and for that reason [it is] important for [those] involved in cross-cultural communication" (Beebe et. al. 1990: 56).

\section{Methods}

\subsection{Participants}

Ninety-four Emirati speakers of English registered in the course titled "Introduction to Linguistics" at a science and technology university in Abu Dhabi participated in this study. Students were on single-gender campuses and, therefore, were in single-gender classes. The introductory linguistics class focused on microlinguistics and functioned as a general education elective credit for the humanities. Of this number, 67 were female and 27 were male. The students' ages ranged between 19 and 24 with a mean age of 21 .

\subsection{Data-collection Tool and Analysis}

Data were collected using a written survey we developed. It was comprised of six sections. The first section collected demographic information; the second asked how often the participants engaged in communication with people from other cultures; the third enquired about how often they met tourists in the UAE; the fourth asked them to indicate the extent to which they would feel comfortable talking to 
an unknown tourist couple (considering cultural orientations within the region, the tourist couple was defined as a husband and wife); and the fifth asked the participants to indicate how comfortable they would be accepting a request of an unknown tourist couple in their early 30s who approached them, complimented them on their traditional clothes and inquired if they could have a photo taken with them, and this section also investigated what they would actually do in such a situation. The options they were given were:

A.I would take a photo with the husband and wife tourists

B. I would not take a photo with the husband and wife tourists

C. I would do neither. Instead, I would

The last section included the following discourse completion task (DCT):

\begin{tabular}{l} 
Write in the space provided what you would say to complete the following \\
conversational situation: \\
The husband and wife (tourists): \\
"Your national clothes look very interesting, and you look so nice in them! \\
Would you mind if we have a photo taken with you?" \\
You: \\
\hline \\
\hline
\end{tabular}

Although written DCTs as a research tool do not collect naturally occurring data, they have been noted to allow researchers to collect data that might be difficult to negotiate in real-life situations (Hartford \& Bardovi-Harlig 1992) as was the case in the current study. Another advantage of written DCTs is that they allow researchers to collect "a large amount of data quickly, [to] create an initial classification of semantic formulas, and [to] ascertain the structure of refusals" (Beebe \& Cumming cited in Cohen 1996: 394).

Data collected were analyzed considering descriptive statistics such as frequencies and averages. T-tests for two independent means were used to make comparisons between the male and the female data sets. A p value of less than 0.05 was considered significant. The components of the refusal speech act set were analyzed considering the scheme by Beebe et al. (1990).

\section{Results}

The main aim of this study was to describe the refusal speech act set produced by Emiratis interacting with tourists. In order to understand the context better, participants were first asked how often they normally engage in communication with people from other countries and how often they meet tourists in the UAE with 
"1" representing "never" and "5" being "always". Results related to these two questions are summarized in Table 2 below.

Table 2

Participants' Engagement in Communication with Those from Distinct Cultures

\begin{tabular}{|c|c|c|c|c|c|c|c|}
\hline & & Min & Max & $\overline{\mathrm{x}}$ & SD & $\mathrm{t}$ & p* \\
\hline \multirow{3}{*}{$\begin{array}{l}\text { How often do you engage in } \\
\text { communication with people } \\
\text { from other countries? }\end{array}$} & Male $(n=27)$ & 2 & 5 & 3.5 & 0.9 & \multirow[b]{2}{*}{-1.1957} & \multirow[b]{2}{*}{0.1174} \\
\hline & Female $(n=67)$ & 1 & 5 & 3.2 & 0.9 & & \\
\hline & All $(n=94)$ & 1 & 5 & 3.3 & 0.9 & & \\
\hline \multirow{3}{*}{$\begin{array}{l}\text { How often do you meet } \\
\text { tourists in the UAE? }\end{array}$} & Male $(n=27)$ & 1 & 4 & 2.4 & 0.7 & \multirow{3}{*}{-1.8903} & \multirow{3}{*}{0.0309} \\
\hline & Female $(n=67)$ & 1 & 4 & 2.7 & 0.8 & & \\
\hline & All $(n=94)$ & 1 & 4 & 2.6 & 0.8 & & \\
\hline
\end{tabular}

${ }^{*} p<0.05$

According to Table 2, the participants reported engaging in communication with people from other countries slightly more often than "sometimes" $(\bar{x}=3.3)$. The average rating of the male participants $(\overline{\mathrm{x}}=3.5)$ was slightly higher than that of the female participants $(\overline{\mathrm{x}}=3.2)$; however, there was no statistically significant difference between their responses $(t=-1.1957, p=0.1174)$. Table 2 also shows that the participants report meeting tourists in the UAE slightly less than "sometimes" $(\bar{x}=2.6)$. This time, however, the average rating for the female participants $(\bar{x}=2.7)$ was slightly higher than that of the male participants $(\overline{\mathrm{x}}=2.4)$ with a difference at a statistically significant level $(\mathrm{t}=-1.8903, \mathrm{p}=0.0309)$.

Data were also collected to answer the first research question related to the extent to which they would feel comfortable talking to an unknown tourist couple and whether their responses changed according to gender. The summary of the data related to this question is given in Table 3 with " 1 " referring to "Very uncomfortable" and "5" representing "Very comfortable".

Table 3

Participants' Feeling of Comfort Speaking to a Tourist Couple

\begin{tabular}{|l|l|c|c|c|c|c|c|}
\hline \multicolumn{2}{|c|}{} & Min & Max & $\bar{x}$ & SD & t & p* \\
\hline \multirow{2}{*}{$\begin{array}{l}\text { How comfortable would you } \\
\text { feel talking to a tourist couple } \\
\text { (husband and wife) that you } \\
\text { have never met before? }\end{array}$} & Male $(n=27)$ & 1 & 5 & 3.9 & 1.2 & -1.2152 & 0.1136 \\
\cline { 2 - 9 } & Female $(n=67)$ & 1 & 5 & 3.7 & 1 & & \\
\cline { 2 - 7 } & All $(n=94)$ & 1 & 5 & 3.7 & 1.1 & & \\
\hline
\end{tabular}

${ }^{*} \mathrm{p}<0.05$

As is seen in Table 3, the participants indicated that they would feel fairly comfortable talking to a tourist couple that they have never met before $(\bar{x}=3.7)$. Although the male participants' responses were slightly higher than that of the females $(\bar{x}=3.9$ and $\bar{x}=3.7)$, there was no difference at a statistically significant level between the two data sets.

The second research question was related to the extent to which the participants would feel comfortable accepting a tourist couple's request for a photo with them 
in their traditional Emirati clothes, and whether or not their responses might be influenced by the gender variable. Results in response to this question can be seen in Table 3 with " 1 " being "Very uncomfortable" and "5" indicating "Very comfortable".

Table 4

Participants' Feeling of Comfort Accepting a Request for a Photo

\begin{tabular}{|l|l|c|c|c|c|c|c|}
\hline \multicolumn{2}{|c|}{} & Min & Max & $\bar{x}$ & SD & t & p* \\
\hline \multirow{2}{*}{$\begin{array}{l}\text { How comfortable would you } \\
\text { feel accepting their request for a } \\
\text { photo with you? }\end{array}$} & Male $(n=27)$ & 1 & 5 & 3.9 & 1.3 & 2.8804 & 0.0024 \\
\cline { 2 - 9 } & Female $(n=67)$ & 1 & 5 & 3.2 & 1.2 & & \\
\cline { 2 - 7 } & All $(n=94)$ & 1 & 5 & 3.4 & 1.3 & & \\
\hline
\end{tabular}

${ }^{*} p<0.05$

Table 4 shows that participants generally indicated that they would feel moderately comfortable $(\overline{\mathrm{x}}=3.4)$ accepting such a request. However, the male participants' average rating $(\overline{\mathrm{x}}-3.9)$ was higher than that of the female participants $(\overline{\mathrm{x}}=3.2)$. As well, the difference between their responses was at a statistically significant level $(\mathrm{t}=2.8804, \mathrm{p}=0.0024)$. Therefore, these results show that the male participants would feel more comfortable than the female participants accepting a request to take a photo with a tourist couple.

The participants were also asked how they would actually behave in such a situation. Their responses are summarized in Figure 1 below.

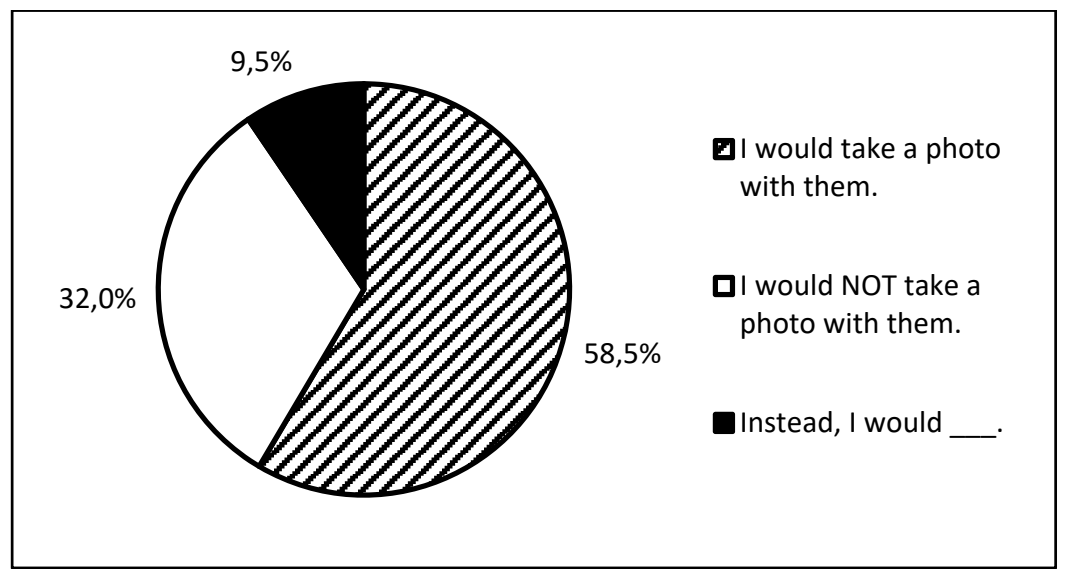

Figure 1. Participants' Choices of Action

According to Figure 1, out of 94 participants, 58.5\% indicated that they would accept the request while $32 \%$ would reject the request and $9.5 \%$ would offer an alternative suggestion, essentially rejecting the initial request. Five of the responses related to the latter, however, included conditional acceptance. Two of the female participants stated that they would agree to take the photo without showing their faces, "I would take the picture, but without my face showing". Other female participants noted responses like "I would take a photo with the wife [but] not the husband," and "I would take a photo only if I am wearing my sheila" [the traditional 
women's headscarf]. One male participant stated he would "take a picture for them without [revealing my face]." Among the other courses of action included suggesting the tourist couple take the photo with a mannequin in traditional clothes, getting them the same traditional clothes, talking to them about the traditional clothes without letting them take a photo, and being kind by offering something else.

In order to ascertain whether the differences in responses between the males and females were statistically significant, a t-test was conducted and the results are in Table 5.

Table 5

Comparison of Data according to Gender

\begin{tabular}{|c|c|c|c|c|c|c|}
\hline & \multicolumn{2}{|c|}{ Accept } & \multicolumn{2}{|c|}{ Refuse } & $\mathrm{t}$ & $\mathrm{p}^{*}$ \\
\hline & $f$ & $\%$ & $f$ & $\%$ & & \\
\hline Male $(n=27)$ & 21 & 78 & 6 & 22 & -2.458 & 0.0079 \\
\hline Female $(n=67)$ & 34 & 51 & 33 & 49 & & \\
\hline All $(n=94)$ & 55 & 58.5 & 39 & 41.5 & & \\
\hline
\end{tabular}

$* p<0.05$

When the male and female participants' responses were compared, it was found that a significantly lower number of the female participants $(51 \%)$ in comparison to the male participants $(78 \%)$ would accept the request. In other words, a considerably higher number of the female participants indicated that they would either reject the request or reject the request by offering an alternative. The t-test showed that there was a significant difference at the .05 level between gender and participants' behavior in the given situation $(\mathrm{t}=-2.458, \mathrm{p}=0.0079)$.

The third research question investigated the semantic components of the refusal speech act set. To this end, 39 participant responses that functioned as a refusal were analyzed. Moreover, the speech act sets were broken down to count each refusal component within the set and categorized based on Beebe et al.'s (1990) classification system. Since the refusal speech act set was produced by only six male participants in comparison to 33 female participants, no inferential statistical comparison was made between the data sets considering the gender variable. The results are summarized in Table 6 .

Of the 84 components of refusal speech act sets produced, $26(31 \%)$ included a statement of regret in response to the request made by the tourist couple. While this was the most frequent component used by both females and males, males used this more frequently ( $45 \%$ vs. $29 \%$ ). All of these, except for two, used the adjective "sorry." The two participants who declined the request without using "sorry" said, "I [would] like to but I cannot," and "No, I cannot do that." It is interesting to note that only two of the responses contained an intensifier to accompany the adjective (i.e., really and so). As well, the adjective was accompanied by the negation word "but" in eight of the utterances. These were all exclusive to the female participants' responses. 
Table 6

Components of the Refusal Speech Act Sets

\begin{tabular}{|l|c|c|c|c|c|c|}
\hline & \multicolumn{2}{|c|}{$\begin{array}{c}\text { Female } \\
\mathrm{n}=75\end{array}$} & \multicolumn{2}{c|}{$\begin{array}{c}\text { Male } \\
\mathrm{n}=9\end{array}$} & \multicolumn{2}{c|}{$\begin{array}{c}\text { Total } \\
n=84\end{array}$} \\
\hline Refusal Components & $f$ & $\%$ & $f$ & $\%$ & $f$ & $\%$ \\
\hline $\begin{array}{l}\text { Statement of regret } \\
\text { Ex. I am sorry. I can't take photo with you. }\end{array}$ & 22 & 29 & 4 & 45 & 26 & 31 \\
\hline $\begin{array}{l}\text { Thank-you note } \\
\text { Ex. Thank you (for your compliment). }\end{array}$ & 20 & 26.5 & 2 & 22 & 22 & 26 \\
\hline $\begin{array}{l}\text { Excuse, reason, explanation } \\
\text { Ex. I can't take photo with you because of our tradition. }\end{array}$ & 19 & 25.5 & 1 & 11 & 20 & 24 \\
\hline $\begin{array}{l}\text { Statement of alternative } \\
\text { Ex. You can take photo with men. }\end{array}$ & 9 & 12 & 1 & 11 & 10 & 12 \\
\hline $\begin{array}{l}\text { Acceptance that functions as a refusal (lack of enthusiasm) } \\
\text { Ex. Umm, I am not sure that it's okay. }\end{array}$ & 4 & 5.5 & 1 & 11 & 5 & 6 \\
\hline $\begin{array}{l}\text { Avoidance (do/say nothing) } \\
\text { Ex... (After a thank you note) }\end{array}$ & 1 & 1.5 & 0 & 0 & 1 & 1 \\
\hline \multicolumn{1}{|c|}{ Totals } & $\mathbf{7 5}$ & $\mathbf{1 0 0}$ & $\mathbf{9}$ & $\mathbf{1 0 0}$ & $\mathbf{8 4}$ & $\mathbf{1 0 0}$ \\
\hline
\end{tabular}

A thank-you note was present in $22(26 \%)$ of the refusals, and there was little difference in terms of percentage of frequency between males and females. These responses often included the performative act of thanking. Examples are "Thank you," "Thank you for your kind words, but ...," "Thank you for your (kind) compliment, but ...," and "That is so sweet of you, thank you so much." One of the responses by a female participant included a compliment in turn: "Thank you, both of you look beautiful, too."

A reason for declining the request was present in $20(24 \%)$ of the total number of refusals. These were all provided by the female participants, except for one. Eight of the reasons were related to the participants' lack of interest in (appearing in) photos. Examples are, "I'm not a big fan of photos," "I don't like being in photos,", and "To be honest, I don't like [to] take photos." Five of the reasons were related to the participants' traditions/culture. They said, for example, "I can't take photo with you because of our tradition," and "It is against our culture to take photo." One male and one female participant indicated the lack of comfort they feel when they are photographed. The following reasons were mentioned one time by five different participants: photos are personal, a father not allowing, personal reasons, physical appearance on the day, and shyness.

Ten of the refusals (12\%) produced by the participants contained a statement of alternative with little difference between the percentages of male and female participants. Six participants suggested that they take the photo with someone else. One female participant, for instance, stated the requester may ask a male. Others said, "My sister may like to," and "I can ask one of my friends to take pictures with you if you wait a second." One female participant offered taking the picture with the wife, but not the husband. One of the male participants rejected by saying "I think it would be better to take a picture of you with your wife to make it an unforgettable moment." Two other female participants, on the other hand, stated 
they would give them the names of the shops where the couple could find traditional clothes. One even offered to accompany them to the shop.

A lack of enthusiasm was present in five $(6 \%)$ of the responses. Although such responses indicated acceptance, they functioned as a refusal. These included three female participants' preference for hiding their faces when taking the photo. Another female participant said, "Umm, I am not sure that it's okay." Similarly, a male participant responded, "I don't mind actually since you asked, but just an advice in the future, it is better to just take a picture of a [mannequin] with the same clothes because some people might see it to be weird and they would feel very uncomfortable." These utterances would likely change the course of action taken by the requester to refrain from threatening the requester's face. This, as well, would help save their own face.

Albeit infrequent (1\%), it is also important to note one female participant's rather limited response. In this response, there was only a thank you note. This, we interpret, as an avoidance strategy, most probably chosen by the participant to save face by not producing an explicit refusal.

We also analyzed the refusals considering linguistic devices utilized by the participants. One of these was the adverbs of intensifiers (i.e., "so" and "very") used to emphasize the apology, which occurred three times in the female data set only ("I am really sorry," and "I am so sorry, but..."). Another one was modality to mitigate the refusal, which again as produced by the female participants only: "I just don't like my pictures to be taken," "Umm, I am not sure that's okay," "I would love to but I am shy," and "I would love to but I cannot." It was also interesting to note the rather infrequent use of 'communicative gifts' to the hearer to express positive emotions, evaluation, and attitude (Iliadi \& Larina 2017). These occurred four times in the female data set and only once in the male data set. The female participants said, "..., both of you look beautiful too," "That's so sweet of you," and "That's nice of you, ...," and "Thank you for your kind words, but ...." The male student said, "Thank you for your kind compliment, but ...." Important to note is that a thank-you note generally preceded these. Taken together, these data show that the participants' use of positive politeness in their refusal speech act sets was limited, and when it was used, it was almost always utilized by the female students.

\section{Discussion}

This study showed that the participants engaged in communication with people from other countries slightly more often than sometimes. However, they stated their interaction with tourists is limited to less than sometimes. Considering the fact that around $88.5 \%$ of the UAE residents are expatriates (GMI 2019) and the increasing number of tourists in the region, the former is somewhat surprising. In fact, it has been observed that an increasing number of young Emiratis are now "entering the country's tourism and entertainments sector, ... interacting with visitors at some of Abu Dhabi's busiest attractions such as Warner Bros. World and Ferrari Word" (Zaatari 2019: parag. 1). However, it is possible that the participants in the current study did not consider obligatory activities such as consultations with expatriate 
faculty when answering the question As well, the observation that "[a] large section of expatriates living in the UAE are unaware of their host country's traditions and many have only learned about things that affect their lives" (Sherif \& de Leon 2012: parag. 10) may have led the participants of this study to keep their interaction with expatriates, and therefore with tourists, to a minimum. Moreover, the possibility of significant cultural distances between Emiratis and non-Emiratis, such as those between Westerners and Arabs (Harrison \& Michailova 2012), might also deter the participants of this study from engaging in much dialogue with expatriates. On the other hand, the limited interaction between local Emiratis and tourists may be due to individual tourists' or tourism agencies' tendency to frequent venues where there is little chance of genuine interaction with locals and local culture (Swan 2016). It has also been observed that tourists may be too shy to speak to Emiratis when they encounter them in touristic places (Seraphim \& Haq 2019). On the other hand, the participants in the current study indicated they would feel fairly comfortable talking to tourists and feel moderately comfortable accepting a tourist couple's request for a photo with them in their traditional clothes. These results are not surprising given that Emiratis take pride in their virtues of courtesy and hospitality as "visitors are sure to be charmed by the genuine friendliness of the people" (Abu Dhabi C. cited in Schwaighofer 2014: 90).

It still is important to note that well over one-third of the participants stated they would either reject the request or suggest a condition with female participants refusing more than male participants at a statistically significant level. Alternatives raised by the female participants included covering their faces or allowing the photo with the female tourist only. This type of refusal is somewhat similar to Tuncer and Turhan's finding that females employed "negative willingness" more regularly (2019). Emirati female participants' reluctance to accept the request may stem from "social forces [that] sometimes prevent women from interacting in public with men outside their families" (Dariela et al. 2017: 4). Past research found that communication between genders in the UAE is normally permissible at work as long as it is on work-related matters; however, purely social interaction between men and women especially outside of the workplace could be seen by some as contrary to Emirati customs and the religion of Islam (Ahmad 2014). In the case of a photo taken with a stranger, the situation may be even more controversial. In fact, Sylvester (2019: parag. 14) warns that "[in the UAE] taking photos of people (particularly women) you haven't met before and who haven't given you their permission is illegal and can lead to arrest or fines."

The last research question aimed to identify the components of the refusal act set produced by the participants. Results revealed that the participants employed non-performative direct refusals, indicating their lack of willingness to accept the request (Leech 1983). It is important to note the participants' avoidance of the negation word 'No' unlike what Tuncer and Turhan found in their study on Turkish males (2019) and their tendency to apologize to the requester. The use of a thankyou note by some participants is also important. In fact, Al Okla (2018) notes that 
members of the Arabic culture often refuse by just saying "Thank you." We interpret these to be directed towards face-saving when confronted by a facethreatening act. As is also indicated by Brown and Levinson (1987), the speaker often utilizes certain linguistic features to alleviate face-threatening acts to make the hearer feel at ease. Beebe et al. (1990) also point to the utilization of adjuncts such as a gratitude to alleviate the impact created by a (forthcoming) refusal. It is also important to note the social distance between a tourist and a local affecting the interlocutors' choices of linguistic politeness. Prompted by the urge to keep a tourist "interested and attached to the place visited" (Garay 2019: 71), the refuser is likely to use positive politeness strategies when performing an act threatening the hearer's face. Interestingly, while the three most frequently used refusal components are similar between the genders, there are differences in the percentage of their use; for example, males used a statement of regret more than females, but females provided an excuse, reason, or explanation much more frequently than males. This supports previous research in that differences in the gender variable might be influenced by situational and socio-cultural factors (Nelson, Batal \& Bakary 2002, Rezvani, Ismael \& Tok 2017, Tuncer \& Turhan 2019). However, it is also interesting to note the participants' limited use of linguistic devices for positive politeness purposes. When they were used, they included modality and intensifiers. There were also instances of communicative gifts to the hearer. The former were used by the females while the latter was produced by one male only. These findings may point to the female Emirati speakers' greater tendency to utilize linguistic features to alleviate the force imposed by the face-threatening act of refusals. However, the lack of literature on Emirati speakers' language use for this purpose prevents us from making stronger deductions. Albeit limited, our findings are expected to shed at least some light on language use by (young) Emirati speakers in a hypothetical situation with unknown tourists.

Necessary to point out is the relatively limited variety of refusal components used by the participants compared to the number of those identified by Beebe et al. (1990). This might be due to the nature of the DTC research tool which may have limited the authenticity of the data collected (Hartford \& Bardovi-Harlig 1992). As well, the variety is impacted by the context in which the role-play in DCT was situated. The refusal speech act set, just like any other, is affected by myriad factors including the nature of the dialogue, the social/power distance between the interlocutors, etc. (Umale 2011). Such factors likely played a role in the refuters' component choices producing the refusal speech act set.

\section{Conclusion}

This investigation of Emirati speakers' self-reported ease in communicating with unknown tourists and their use of the refusal speech act found that they would feel comfortable engaging in communication and accepting the couple's request to take a photo with them. However, female participants reported feeling less comfortable and more likely to refuse the request at a statistically significant level. 
Linguistic analysis of the refusal speech act, as demonstrated in hypothetical conversation via the DCT, revealed that very few refusal components were utilized and the most common components were a statement of regret, a thank-you note, and an excuse, reason or explanation. Moreover, participants employed nonperformative direct refusals and avoided the use of the negation word 'No', most likely to put the hearer at ease during what could be considered a face-threatening linguistic exchange. In terms of differences in use of refusal components between the genders, while the three most frequently used components are similar, there are differences in the percentage of their use; for example, males use a statement of regret more than females, but females provide an excuse, reason, or explanation much more frequently than males. Results also showed that the refusal speech act produced by the Emirati speakers included few linguistic devices as a positive politeness strategy, and these were in the form of modality, intensifiers, and communicative gifts, almost all of which were utilized by the female participants only. Albeit the small sample size, these results point to certain trends in language use by young Emiratis with a set of cultural values. It is, therefore, important to note the way in which cultural characteristics inform speakers' communicative behavior and styles, as well as saturate language use with impacts at all linguistic levels (Larina 2020).

While these discoveries offer some awareness into an under-investigated area, sole use of a DCT has limitations due to it being a self-report of a role-play communicative exchange. Therefore, future research into the use of refusals in this particular situation might employ different techniques like interviews with tourists and Emiratis after they interacted with tourists and observations. More general research into the refusal speech act used in the Emirati population could consider different types of situations (contextual as well as linguistic L1/L2), different age groups, and social/power distance between the speakers. This could provide more insight into the specific uses within the culture and across cultures.

The speech act of refusals can be a face-threatening event that every human will experience. As shown by the current study and the previous research, challenges with such face-threatening acts can be more formidable during exchanges with people from distinct cultures from ours. The fact that we are more able and required to interact with such people necessitates our developing an understanding of the nuances of communication and appropriate responses so that communication breakdowns can be avoided and the overall well-being of everyone involved in the interaction is enhanced.

(C) Deveci Tanju and Jessica Midraj, 2021
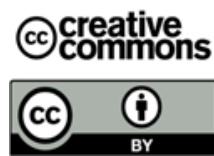

This work is licensed under a Creative Commons Attribution 4.0 International License https://creativecommons.org/licenses/by/4.0/ 


\section{REFERENCES}

Abed, Qadoury A. 2011. Pragmatic transfer in Iraqi EFL learners' refusals. International journal of English Linguistics 1 (2). 166-185.

Ahmad, Zaman K. 2014. Gender differences and work-related communication in the UAE: A qualitative study. International Journal of Business and Management 9 (3). 185-195.

Al Murshidi, Hassan G. 2014. Emirati and Saudi students' writing challenges at U.S. universities. English Language Teaching 7 (6). 87-95.

Al Nawrasy, Omar. 2013. The effect of native and nonnative English language teachers on secondary students' achievement in speaking skills. Jordan Journal of Educational Sciences 9 (2). 243-254.

Al Okla, Nour. 2018. Verbal and non-verbal refusal strategies in English: Refusing promotions. Arab World English Journal 9 (1). 321-334. DOI: 10.24093/awej/vol9no1.23

Austin, John L. 1962. How to Do Things with Words. Cambridge, MA: Harvard University Press.

Barlow, Lisa. 2009. The effects of nonnative speaker accent on EFL students' listening comprehension (Unpublished doctoral dissertation). The University of Exeter, Exeter.

Bauman, Richard \& Joel Sherzer. 1975. The ethnography of speaking. Annual Review of Anthropology 4. 95-119.

Beebe, Leslie M., Tomoko Takahashi \& Robin Uliss-Weltz. 1990. Pragmatic transfer in ESL refusals. In Robin Scarcella, Elaine S. Andersen, \& Stephen D. Krashen (eds.), Developing communicative competence in a second language, 55-73. New York: Newbury House.

Brown, Penelope \& Stephen C. Levinson. 1987. Politeness: Some Universals in Language Usage. Cambridge: Cambridge University Press.

Chojimah, Nurul. 2015. Refusal and politeness strategies in relation to social status: A case of face-threatening act among Indonesian university students. Theory and Practice in Language Studies 5 (5). 906-918. DOI: 10.17507/tpls.0505.04

Cohen, Andrew D. 1996. Speech acts. In Sandra L. McKay \& Nancy H. Hornberger (eds.), Sociolinguistics and language teaching, 383-420. Cambridge: Cambridge University Press.

Crystal, David. 1985. A dictionary of Linguistics and Phonetics. $2^{\text {nd }}$ edn. New York: Basil Blackwell.

Dariela, Aurelie, Curtis Kepharta, Nikos Nikiforakisa \& Christina Zenkerb. 2017. Emirati women do not shy away from competition: Evidence from a patriarchal society in transition (Working paper 0011). Retrieved from New York University Abu Dhabi, Division of Social Science Working Paper Series. URL: https://nyuad.nyu.edu/content/ dam/nyuad/academics/divisions/social-science/working-papers/2017/0011.pdf (accessed 12 March 2020).

Deveci, Tanju. 2018. Student perceptions on collaborative writing in a project-based learning course. Universal Journal of Educational Research 6 (4). 721-732. DOI: 10.13189/ ujer.2018.060415

Deveci, Tanju. 2015. The complaint speech act set produced by university students speaking English as a foreign language. [Special Issue]. Literacy Information and Computer Education Journal 4 (1). 2161-2171.

Deveci, Tanju \& Ikhlas Bin Hmida. 2017. The request speech act in emails by Arab university students in the UAE. Journal of Language and Linguistic Studies 13 (1). 194-214.

Deveci, Tanju, Jessica Midraj \& Wael El Sokkary. 2021. "You are the best professor!" Emirati university students' utilization of the compliment speech act. Manuscript submitted for publication. 
Félix-Brasdefer, Cesear J. 2009. Interlanguage refusals: Dispreferred responses in interlanguage pragmatics refusal sequences in learner-NS interactions. Applied Language Learning 19. 1-27.

Garay, Jovanie B. 2019. Linguistic politeness of tourism personnel: Social interaction among local tourists in context. International Journal of Linguistics, Literature and Translation 2 (5). 55-82. DOI: 10.32996/ijllt.2019.2.5.9

Harrison, Edelweiss \& Snejina Michailova S. 2012. Working in the Middle East: Western female expatriates' experiences in the United Arab Emirates. The International Journal of Human Resource Management 23 (4). 625-644.

Hartford, Beverly S. \& Kethleen Bardovi-Harlig. 1992. Experimental and observational data in the study of interlanguage pragmatics. Pragmatics and Language Learning 3. 33-52.

Hedayatnejad, Fariba, Roohollah Maleki \& Ali A. H. Mehrizi, A. 2015. The effect of social status and gender on realization of refusal of suggestion among Iranian EFL intermediate learners. Journal of Language Teaching and Research 7 (1). 99-109.

Iliadi, Paraskevi-Lukeriya \& Tatiana V. Larina. 2017. Refusal strategies in English and Russian. RUDN Journal of Language Studies, Semiotics and Semantics 8 (3). 531-542.

Jandt, Fred E. 2018. An Introduction to Intercultural Communication. $9^{\text {th }}$ edn. Los Angeles: SAGE.

Johnson, Danette I., Michael E. Roloff \& Melissa A. Riffee. 2004. Politeness theory and refusals of requests: Face threat as a function of expressed obstacles, Communication Studies 55 (2). 227-238. DOI: 10.1080/10510970409388616

Khameis, Mona. 2007. Using Creative strategies to promote students' speaking skills. In Kay Gallagher \& Khadar Bashir-Ali (eds.), Action research and initial teacher education in the UAE. Perspectives from teacher education at the Higher Colleges of Technology, 109-118. Abu Dhabi: HCT Press.

Kross, Ethan, Marc G. Berman, Walter Mischel, Edward E. Smith \& Tor D. Wager. 2011. Social rejection shares somatosensory representations with physical pain. In Proceedings of the National Academy Sciences 108 (15). 6270-6275. DOI: 10.1073/pnas.1102693108

Larina, Tatiana. 2020. 'Sense of privacy' and 'sense of elbow': English vs Russian values and communicative styles. In Helen Bromhead \& Zhengdao Ye (eds), Meaning, life and culture: In conversation with Anna Wierzbicka. Canberra: Australian National University Press.

Larina, Tatiana V. 2015. Culture-specific communicative styles as a framework for interpreting linguistic and cultural idiosyncrasies. International Review of Pragmatics 7. 195-215. DOI: $10.1163 / 18773109-00702003$

Larina, Tatiana V., Vladimir I. Ozyumenko \& Svetlana Kurtes. 2017. I-identity vs we-identity in language and discourse: Anglo-Slavonic perspectives. Lodz Papers in Pragmatics 13 (1). 109-128. DOI: 10.1515/lpp-2017-0006

Leary, Mark R. 2015. Emotional responses to interpersonal rejection. Dialogues in Clinical Neuroscience 17 (4). 435-441.

Leech, Geoffrey N. 1983. Principles of Pragmatics. London: Longman.

Low, Linda. 2012. Abu Dhabi's Vision 2030: An Ongoing Journey of Economic Development. Singapore: World Scientific Publishing.

Merhpour, Saeed, Masoume Ahmadi \& Naser Sabourian Zadeh. 2016. Cross-linguistic comparison of refusal speech act: Evidence from trilingual EFL learners in English, Farsi, and Kurdish. Iranian Journal of Applied Language Studies 8 (2). 159-188.

Mokhtari, Nargol. 2015. Face-threatening aspect of refusal speech acts: a contrastive study. Journal of Modern Research in English Language Studies 2 (1). 84-73. 
Nelson, Gayle L., Mahmoud Al Batal \& Waguida El Bakary. 2002. Directness vs. indirectness: Egyptian Arabic and US English communication style. International Journal of Intercultural Relations 26. 39-57.

Nunn, Roger, Tanju Deveci \& Hussain Salih. 2015. Phenomenological views of the development of critical argumentation in learners' discourse. The Asian EFL Journal Professional Teaching Articles 85. 90-116.

Rezvani, Mahsa, Darya A. Ismael \& Samet Tok. 2017. Speech act of refusal among English language teaching students. The International Journal of Research in Teacher Education 8 (2). 1-11.

Richards, Jack, John Plat J. \& Heidi Weber. 1985. Longman dictionary of applied linguistics. England: Longman.

Schwaighofer, Verana. 2014. Tourist Destination Images and Local Culture: Using the Example of the United Arab Emirates. Wiesbaden: Springer Gabler.

Searle, John R. 1977. Speech Acts: An Essay in the Philosophy of Language. Cambridge. Cambridge University Press.

Searle, John R. 2002. Speech acts, mind, and social reality. In Günther Grewendorf \& Georg Meggle (eds.), Speech Acts, Mind, and Social Reality: Discussions with John R. Searle, 3-6. The Netherlands: Kluwer Academic Publishers.

Seraphim, Joanna \& Farooq Haq. 2019. Challenges for promotion of heritage tourism: Case study of the UAE. In Surabbi Srivastava (eds.), Conservation and promotion of heritage tourism, 35-56. Hershey, PA: IGI Global.

Shishavan, Homa B. \& Farzad Sharifian 2016. The refusal speech act in a cross-cultural perspective: A study on Iranian English-language learners and Anglo-Australian speakers. Language \& Communication 47. 75-88. DOI: 10.1016/j.langcom.2016.01.001

Sokolskaya, Eugenia. 2015. Directness in Russia's high-context culture. Paper presented at Midwest Slavic Conference, Coumbus, $\mathrm{OH}$.

Tanck, Sharyl. 2004. Speech act sets of refusal and complaint: A comparison of native and nonnative English speakers' production. TESOL Working Papers 2. 1-22.

Tuncer, Hulya \& Burcu Turhan. 2019. Refusal strategies of Turkish pre-service teachers of English: A focus on gender and status of the interlocutor. Journal of Language and Linguistic Studies 15 (1). 1-19.

Umale, Jaishree. 2011. Pragmatic failure in refusal strategies: British versus Omani interlocutors. Arab World English Journal 2 (1). 18-46.

\section{Электронные ресуры / Internet Resources}

Dubai Tourism. 2020. Annual visitor report 2019. URL: https://www.dubaitourism.gov.ae/en/ research-and-insights/annual-visitor-report-2019 (accessed: 16 October 2020).

GMI. 2019, January 30. United Arab Emirates population statistics. URL: https://www.globalmediainsight.com/blog/uae-population-statistics/ (accessed: 16 October 2020).

Sherif, Iman \& Janice Ponce de Leon. 2012. Most expatriates in the UAE ignorant about Emirati culture. Gulf News. URL: https:/gulfnews.com/uae/most-expatriates-in-the-uae-ignorantabout-emirati-culture-1.979254 (accessed: 18 March 2020).

Sylvester, Phil. 2019, September 3. Sharia law and the UAE: What you need to know. World Nomads. URL: https://www.worldnomads.com/travel-safety/middle-east/unitedarab-emirates/what-you-can-or-cant-do-in-the-united-arab-emirates (accessed: $18 \mathrm{March}$ 2020). 
Swan, Melanie. 2016, April 30. Emiratis crucial to UAE's tourism success. The National. URL: https://www.thenational.ae/business/travel-and-tourism/emiratis-crucial-to-uae-s-tourismsuccess-1.136995 (accessed: 18 September 2020).

Tesorero, Angel. 2019, December 29. Legendary Emirati hospitality makes UAE a tourist paradise. Khaleej Times. URL: https://www.khaleejtimes.com/uae/dubai/legendaryemirati-hospitality-makes-uae-a-tourist-paradise (accessed: 19 October 2020).

Zaatari, S. 2019, September 14. More Emiratis getting involved in tourism, leisure jobs. Gulf News. URL: https://gulfnews.com/uae/more-emiratis-getting-involved-in-tourism-leisurejobs-1.66026220 (accessed: 19 October 2020).

\section{Article history:}

Received: 24 October 2020

Accepted: 22 January 2021

\section{История статьи:}

Дата поступления в редакцию: 24 октября 2020

Дата принятия к печати: 22 января 2021

\section{Bionotes:}

Tanju DEVECI is Associate Professor of English in the English Department of Khalifa University of Science and Technology in Abu Dhabi, UAE. He taught English for academic purposes at Bilkent and Sabanci Universities in Turkey. Since 2012, he has been teaching English and communication skills to engineering students at Khalifa University in Abu Dhabi. He has published research and teaching articles on a wide range of topics including andragogy, learning styles and pragmatics.

\section{Contact information:}

The English Department, Khalifa University of Science and Technology

Al Saada St. Muroor Road, Abu Dhabi, UAE, 127788

e-mail: tanjudeveci@yahoo.com

ORCID: 0000-0001-5905-9793

Jessica MIDRAJ, PhD, is a faculty member in the English Department at Khalifa University of Science and Technology in Abu Dhabi, UAE. She has extensive experience as an instructor, mentor, teacher-trainer, researcher and administrator. Her research interests include quality assurance, student and teacher self-efficacy, language issues in STEM education and curriculum and assessment.

\section{Contact information:}

The English Department, Khalifa University of Science and Technology

Al Saada St. Muroor Road, Abu Dhabi, UAE, 127788

e-mail: jessica.midraj@ku.ac.ae

ORCID: 000-0002-9575-538X

\section{Сведения об авторах:}

Танджу ДЕВЕЧИ - доцент кафедры английского языка Научно-технологического университета Халифа в Абу-Даби, ОАЭ. Преподавал английский для академических целей в Билькентском и Сабанджийском университетах. С 2012 г. преподает английский язык и коммуникацию студентам инженерных специальностей в Университете Халифа в Абу-Даби. Имеет публикации, посвященные широкому кругу проблем, включая стили обучения и прагматику. 


\section{Контактная информация:}

The English Department, Khalifa University of Science and Technology

Al Saada St. Muroor Road, Abu Dhabi, UAE, 127788

e-mail: tanjudeveci@yahoo.com

ORCID: 0000-0001-5905-9793

Джессика МИДРАДЖ - имеет степень $\mathrm{PhD}$, преподает на кафедре английского языка Научно-технологического университета Халифа в Абу-Даби, ОАЭ. Имеет большой опыт как преподаватель, наставник, методист, исследователь и руководитель. Ее научные интересы включают личную эффективность студента и преподавателя, контроль качества, языковые проблемы STEM-образования, учебные планы и их оценку.

\section{Контактная информация:}

The English Department, Khalifa University of Science and Technology

Al Saada St. Muroor Road, Abu Dhabi, UAE, 127788

e-mail: jessica.midraj@ku.ac.ae

ORCID: 000-0002-9575-538X 